\title{
Moderating Influence Of Organizational Reward System On Employee's Performance
}

\section{Kowo Solomon Akpoviroro}

PhD, Department of Business and Entrepreneurship, Kwara State University, Malete Nigeria

\section{Popoola Mufutau Akanmu}

PhD, Department of Business Administration, Kwara State University, Malete Nigeria

\section{Akinrinola Olalekan}

$\mathrm{PhD}$, Department of Accounting, Babcock University Ogun State, Nigeria

\section{Salau Abdulazeez Alhaji}

PhD, Department of Business and Entrepreneurship, Kwara State University, Malete Nigeria

\begin{abstract}
This study explored the relationship between organizational reward system and employee performance. Competition has become tenser in various sectors of the economy, organizations are harsh to boost employee morale at work and this situation requires management to be more careful in setting up reward system and remunerations to its employees in addition to their wages and salaries. The objectives of the study are to examine the effect of Employee Benefit on Job Performance and also to investigate the effect of Work Bonuses on Employees Motivation. 124 copies of questionnaire were administered to Cadbury Plc employees in Lagos State, Nigeria to get primary data that treated and tested appropriate research questions and hypotheses accordingly. For the purpose of this study, correlation and descriptive research was employed. The Yamane formula was adopted to determine the sample size. The Statistical Package for Social Sciences and Cronbach's alpha was employed. The study found out that employee bonus significantly affects employee motivation in business and employee benefit significantly affects job satisfaction in business. The study recommends that organizations need to have a reward system(s) as a standard which is considered fair and equitable. Not having a reward system in an organization will lead to resistance from the employees and also Incentive management and practices such as pay incentives and fringe benefits should be based on realistic and standard methods in accordance with industrial benchmarks, indices and procedures and should likewise conform to ethical valuations and practices.
\end{abstract}

Keywords: employee benefit, job performance, work bonuses, employees motivation, reward.

JEL Classification: M52, M12, E42.

Cite as: Akpoviroro, K.S., Akanmu, P.M., Olalekan, A., Alhaji, S.A. (2018). Moderating Influence Of Organizational Reward System On Employee’s Performance. SocioEconomic Challenges, 4(2), 114-122. https://doi.org/10.21272/sec.4(2).114-122.2018.

(C) The Authors, 2018. This article is published with open access at Sumy State University.

\section{Introduction}

There is extensive literature on performance in work environment, yet little of this literature has studied the link between employment policies and job performance (Ismail \& Abdrasak, 2016). Mafini \& Dlodlo (2014) opined that bonuses are widely used in organizational life to motivate employees. However, does this motivation really show in their performance? Thus the effect of bonuses (monetary rewards) on performance in organizations has been inconclusive in the literature. Khan et al. (2014) point that bonus Systems are becoming a standard and therefore needed in an organization to attract employees. It is important to know how to use it to the organization's advantage and get the best performance from employees (Mangi et al., 2011).Most studies on bonuses have been conducted in the United States probably because reward systems including bonuses are quite common in the United States but the usage of reward systems including bonuses is also rapidly growing in Africa and the rest of the world (Mbandu, 2011; Ombimma, 2014, Rehman et al., 2013 \& Tezera, 2014; Adeoye \& Field, 2014). Therefore it is interesting to study the relations between reward system and employee 
productivity. Sharp (2008) notes that the quest for an effective method of compensating workers has over the years served as a very big challenge to business leaders and organizations: this is a result of the fact that it goes a long way in determining the performance in the organizational output. Ghafoor (2014) opined that recognition is considered one of the best methods of rewarding employees; also a major factor for increase in staff productivity is job satisfaction when an employee is dissatisfied, there will be an obvious decrease in his productivity and output. Moloantoa (2015) posit that the happier people are perform better, the more satisfied they are said to be and more content with their job. Verret (2012) Nevertheless, it has been discovered that some organizations fail to recognize employee effort and this can result in unhappy employees. Therefore it is important to determine the influence of reward system on staff performance. Asegid et al. (2014) observed that most organizations have policies that are not favourable to the employees. Policies on wage administration, benefits, appraisal, promotion, qualification etc may be very rigid and not suitable and at such compliance becomes very difficult. Maximum performance therefore is not obtained from employees. Against this ground, it is expedient that this research amongst other aforementioned problems attempt to analyze the influences of organizational reward system on employee's performance.

\section{Research Questions}

i. How does work bonus influence employee's motivation?

ii. To what extent has employee benefit affected job satisfaction?

\section{Research Hypothesis}

\section{Hypothesis One}

$\mathrm{Ho}_{1}$ Work bonuses have no significant influence on employee's motivation

$\mathrm{Ha}_{1}$ Work bonuses have significant influence on employee’s motivation

\section{Hypothesis Two}

$\mathrm{Ho}_{2}$ Employee benefit has no significant effect on job satisfaction

$\mathrm{Ha}_{2}$ Employee benefit has significant effect on job satisfaction

\section{Operationalization of Research Construct}

Operationalization of variables refers to the method of breaking down variables into operational components for the purpose of measurement and evaluating them into specific contribution to the dependent variable (Asika, 1991).

Independent variable-these are variables that cause a change on the dependent variable. In operationalizing the topic "reward system and workers" productivity"

Mathematically, $Y=f(x)$

$Y$ is the dependent variable, $X$ is the independent variable, $Y$ is the workers' productivity, $X$ is the reward system.

That is;

$Y=y_{1}, y_{2} \ldots \ldots \ldots \ldots \ldots \ldots \ldots \ldots \ldots$

Where $Y_{1}$ is the employee motivation, $Y_{2}$ is the employee job satisfaction, $Y_{\mathrm{n}}$ (infinity).

That is;

$X=x_{1,} X_{2} \ldots \ldots \ldots \ldots \ldots \ldots \ldots \ldots \ldots \ldots$

Where $X_{1}$ are the cash bonuses, $X_{2}$ are the fringe benefits. 


\section{Literature Review}

\section{Concept of Work Bonuses}

Strydom (2011) postulates that bonuses are extrinsic monetary rewards, usually a large sum of money given once at the end of the year. Often these types of rewards are less preferred as opposed to intrinsic or nonmonetary extrinsic rewards, since bonuses have a higher financial impact. The academics and practitioners in favor of bonuses believe that using bonuses increases productivity and organizational performance (Tettey 2006, Hussein \& Idris, 2012; Art, 2010; Bakan \& Buyukbese, 2013). For instance, Ibrahim \& Boerhaneodin (2010) studied the effect of bonuses on employee selection and the results indicated that the selection of more superior employees is enhanced if the contracts include a high cash bonus. Clark, Kristensen \& Westergard (2009) found that bonuses do enhance productivity in sales. On the other hand, bonuses caused sales employees, who were unlikely to make quota, reduce their effort. But this effect was more than compensated for by the increased productivity of the other sales employees (Daft, 2009). Additionally, more frequently bonuses (quarterly) help to improve performance of the weak performers to achieve their annual sales quotas (Bustaman, Teg \& Abdullah, 2014) On the other side are the opposes of bonuses who suggest that bonuses lead to higher pay inequality which results in greater employee turnover and thus has less desirable long-term effects (Aydodgu \& Asikgi, 2011; Bagraim et al., 2007; Waal \& Gordon, 2009). For instance, bonuses could be used to manipulate employees and stimulate feelings of control and distrust (Swanepoel \& Popoola, 2007). This finding was supported by the research of Terera \& Ngirande (2014) which concluded that employee's perceived exposure to random bonuses as unfair, providing them a justification for negative reciprocity, which led to increased cheating. This could explain the increase in financial fraud within multinationals. Verret (2012) Found that fraud often occurs when there is a combination of high targets and high rewards. Strydom (2011) opined that despite the previous mentioned disadvantages, bonuses are becoming more common. An explanation for this is that bonuses could simply be a hygiene factor. Meaning, organizations need to have a reward system(s) as a standard which is considered fair and equitable. Not having a reward system in an organization will lead to resistance from the employees (Ray \& Ray, 2011).

\section{Bonuses and Job Performance}

As bonuses are becoming more a standard in organizational life, it is necessary to know what influences the receivement of bonuses. A key factor that could predict receiving bonus is job performance(Letele, 2012).The common assumption is that if you perform well you get rewarded, congruent to the well-known saying "Hard work pays off", but does it in reality? Does high performance really lead to high bonuses? Top management often gets a much higher bonus than lower level employees, even when they don't necessarily perform better (Mustapha, 2013). On the other hand, there is a rising trend to use pay for performance systems (PFP) related to bonus (Noor, 2013). Most organizations (in the United States) claim using pay for performance (PFP) systems. Additionally, the U.S employees voiced that they would like to be paid for their performance (Millan, 2013; Salisu, Chinyio \& Suresh, 2015).Given the importance of performance and compensation, organization need to validate if there is indeed a relationship between performance and bonuses. Further, there is need to validate if the so-called PFP systems are really structured in a way that they are paying for performance happiness and satisfaction (Onukwwube, 2012).

\section{The Influence of Rewards and Job Satisfaction on Employees}

Kipkebut (2010) states that Reward system researches in recent time rested essentially on the need for organizations to motivate employees in areas of remuneration, work design, corporate structure and guard against tedious work environment for employees to sustain growth and make more profit for the organization in focus and militating against employee turnover in order to satisfy consumers through quality product offerings. Mangi et al (2011) emphasized that advancing on reward processes usually impacts positively on the performance of the corporations. Existing literature shows that this conclusion is valid in most sectors especially the Food and manufacturing sector.

\section{Relationship between adequate compensation and motivation}

Rehman et al. (2013) Postulates that Money is a Generalized Conditional Rein forcer because it is usually paired with primary rein forcers; a Conditioned Incentive because the repeated pairing of money with primary incentives establish a new learned drive for money; an Anxiety Reducer because people become anxious in the absence of money; a Hygiene Factor because it serves as a potential dissatisfaction if not sufficiently 
available and an Instrument for Gaining Desired Outcomes because it helps to acquire other desired outcomes and while it has no value in itself, it but symbolizes intangible goals". (Maloantoa, 2015) "Money is thus a critical motivational variable due to its five general roles already discussed. In addition to these general roles, the features of the pay policies, the type of job, the personality of the individual workers and their preferences and perceptions also intervene in the motivational value of monetary compensation (Ray \& Ray, 2011). Thus, while the US workers rated benefits as the highest, Nigerians rated it second and the Nigerian sample rated training and development first, a variable rated 13 out of 20 by the US respondents”. States that thus in practical terms, these are the variables that are close to the hearts of Nigerian Knowledge Workers (Adeoye \& Field, 2014). The pre-eminence position attached to training and development is in tandem with theoretical and empirical evidences. In most surveys, training appears among the top three benefits sought by employees because they want the opportunities to learn and grow and they search for organisations that will facilitate their professional growth (Judge et al., 2010). Mustapha (2013) emphasized that "it was common for men in the category of wage employment to be thinking in terms of finding a job in order to accrue savings for rural investment on their return from the urban center to their rural areas". Noor (2013) posit that "wage labor has become fully integrated into the normal life of the African worker and that wage labor is not only a means of earning one's living but has become an end in itself". Millan (2013) note that "wages and salaries should not only be adequate but they must also show some element of equity; this is, particularly, true from the view point of the employees. Anything short of a fair and equitable wage or reward can quickly attract the wrath of employees in an economy such as any African country. Ombima (2014) opined that for any average African employee, wages or salaries are highly critical issues. They are decisive because without them in sufficient quantities, life becomes extremely precarious for the worker and members of his/her family. As direct financial rewards, wages and salaries are the most emphasized by the employees, thus, they sort of take a center stage in the scheme of things as far as rewards for work is concerned".

\section{Methodology}

In this study, the survey method was adopted to collect respondent view about the study through the use of questionnaire. 124 copies of questionnaire were administered to Cadbury Plc staffs in Lagos State, Nigeria to get primary data that treated and tested appropriate research questions and hypotheses accordingly. For the purpose of this study, correlation and descriptive research was employed. The yard's formula was adopted. The Minimum Returned Sample Size Table for Continuous Categorical Data by Cresswell (2007) was applied. However, for this research, the Yamane formula was used to determine the sample size. This is calculated below:

The Yamane formula

$N=N / 1+N(e) 2$

Where:

$\mathrm{n}$ is a sample size, $N$ is a population, $e$ is the margin of error (0.05).

Therefore to determine the sample size of this research, the researcher made use of the estimated population of 180 employees. Substituting in the formula above, we have the sample size determination:

Therefore; $n=N / 1+N(\mathrm{e}) 2$

Therefore;

$N=180 / 1+180(0.05) 2$

$N=124$

The sample size of this research is 124 respondents from the population. This is because the nature of this research seeks to collect data from the direct participants of the research project.

The questionnaire used in this survey is closed ended questionnaire; the questionnaire involved "Strongly Agree, Agree, Undecided, Disagree, Strongly Disagree” structured dichotomy questions to facilitate analyzing the data collected from the research. The Likert-Scale form of questionnaire was used in this study. In this study the Statistical Package for Social Sciences and (Cronbach's alpha) was employed. 
Table 1. Reliability Statistics

\begin{tabular}{|c|c|c|c|}
\hline Cronbach's Alpha & & $\mathrm{N}$ of Items & \\
\hline . & .836 & & 38 \\
\hline
\end{tabular}

Source: Field Survey, 2017.

Table 2. Distribution of respondents and response rate

\begin{tabular}{|l|l|l|}
\hline Respondents Occupation & Questionnaire administered (sampled) & Percentage of total response (\%) \\
\hline Top Level & 25 & 24.2 \\
\hline Middle Level & 15 & 14.6 \\
\hline Level Lower & 63 & 61.2 \\
\hline Total & 103 & 100.0 \\
\hline Gender/Category & Questionnaire administered (sampled) & Percentage of total response (\%) \\
\hline Male & 59 & 57.3 \\
\hline Female & 44 & 42.7 \\
\hline No of Returned & \multicolumn{1}{c}{103} & \\
\hline No of Not Returned & 21 & \\
\hline Total no of Questionnaires & 124 & 17 \\
\hline
\end{tabular}

Source: Field Survey, 2017.

\section{Data Analysis and Hypothesis Testing}

Table 3. The descriptive statistics of organizational reward system on employee's Performance

\begin{tabular}{|l|c|c|}
\hline \multicolumn{1}{|c|}{ Responses } & \multirow{2}{*}{ Total (N) } & Mean \\
\hline Work Bonuses And Employees Motivation & 103 & 4.36 \\
\hline organization considers bonus as a major part of its reward system. & 103 & 3.78 \\
\hline Employees are conscious of bonuses given to put in more effort. & 103 & 3.59 \\
\hline Bonuses are considered for employees at appropriate time. & 103 & 3.99 \\
\hline Bonuses given to employees are worthwhile per time. & 103 & 3.79 \\
\hline Employees are motivated by regular bonuses offered in the organization. & Total & Mean \\
\hline Employee Benefit And Job Satisfaction. & 103 & 3.78 \\
\hline It is part of management policies for employee benefits to be given. & 103 & 3.72 \\
\hline Employees are encouraged to work more because of benefit rewards. & 103 & 3.57 \\
\hline Employee benefits are competitive in line with industry standards. & 103 & 3.68 \\
\hline Benefits include monetary and non-monetary rewards in the organization. & 103 & 3.73 \\
\hline Employee benefits are considered reasonable when given to workers. & 103 & 3.55 \\
\hline Employee benefits has been satisfactory as a result of corporate appreciation. & 103 \\
\hline
\end{tabular}

Source: Field Survey, 2017.

\section{Hypothesis Testing}

\section{Hypothesis One}

$\mathrm{Ho}_{1}$ Work bonuses have no significant influence on employee's motivation.

$\mathrm{Ha}_{1}$ Work bonuses have significant influence on employee's motivation.

Table 4. Model Summary

\begin{tabular}{|c|c|c|c|c|}
\hline Model & $\mathrm{R}$ & R Square & Adjusted R Square & Std. Error of the Estimate \\
\hline 1 & $.590(\mathrm{a})$ & .348 & .342 & .49223 \\
\hline
\end{tabular}

Note: ${ }^{a}$ Predictors: (Constant), EMPLOYEEBONUSES. 
Table 5. ANOVA (b)

\begin{tabular}{|l|l|c|c|c|c|c|}
\hline \multirow{2}{*}{ Model } & & Sum of Squares & Df & Mean Square & F & Sig. \\
\hline \multirow{2}{*}{1} & Regression & 13.075 & 1 & 13.075 & 53.965 & $.000(\mathrm{a})$ \\
\cline { 2 - 7 } & Residual & 24.472 & 101 & .242 & & \\
\cline { 2 - 7 } & Total & 37.547 & 102 & & & \\
\hline
\end{tabular}

Notes: ${ }^{a}$ Predictors: (Constant), EMPLOYEEBONUSES. ${ }^{\mathrm{b}}$ Dependent Variable: EMPLOYEEMOTIVATION $($ R square $=0.348)$.

Fcal 53.965 at 0.0001 significance level.

Employee bonuses significantly affect employee motivation in business.

Thus, the decision would be to reject the null hypothesis $\left(\mathrm{H}_{0}\right)$, and accept the alternative hypothesis $\left(\mathrm{H}_{1}\right)$.

Table 4. Coefficients (a)

\begin{tabular}{|l|l|c|c|c|c|c|c|}
\hline \multirow{2}{*}{ Model } & \multirow{2}{*}{} & \multicolumn{2}{|c|}{ Unstandardized Coefficients } & $\begin{array}{c}\text { Standardized } \\
\text { Coefficients }\end{array}$ & T & Sig. \\
\cline { 3 - 8 } & & $\mathrm{B}$ & Std. Error & Beta & B & Std. Error \\
\hline 1 & (Constant) & 1.458 & .226 & & 6.452 & .000 \\
\cline { 2 - 8 } & EMPLOYEEBONUSES & .438 & .060 & .590 & 7.346 & .000 \\
\hline
\end{tabular}

Note: ${ }^{a}$ Dependent Variable: EMPLOYEEMOTIVATION.

The model is shown mathematically as follows;

$Y=a+b x$

Where $y$ is increase in motivation and $x$ is employee bonuses

$($ MOTIVATION $)=1.458+0.438$ EMPLOYEEBONUSES .

This means that for every $100 \%$ change in employee motivation, employee bonuses contributed $43.8 \%$. The result of findings of this research is applicable to the views and findings of Tettey (2006), Hussein \& Idris (2012); Art, (2010); Bakan \& Buyukbese, (2013), Ibrahim \& Boerhaneodin (2010) Clark, Kristensen \& Westergard (2009); that using bonuses increases productivity and organizational performance. Selection of more superior employees is enhanced if the contracts include a high cash bonus. And also bonuses do enhance productivity in sales.

\section{Hypothesis Two}

$\mathrm{Ho}_{2}$ Employee benefit has no significant effect on job satisfaction

$\mathrm{Ha}_{2}$ Employee benefit has significant effect on job satisfaction

Table 7. Model Summary

\begin{tabular}{|l|c|c|c|c|}
\hline Model & $\mathrm{R}$ & $\mathrm{R}$ Square & Adjusted R Square & Std. Error of the Estimate \\
\hline 1 & $.728(\mathrm{a})$ & .530 & .526 & .57698 \\
\hline
\end{tabular}

Note: ${ }^{a}$ Predictors: (Constant), EMPLOYEEBENEFITS.

Table 8. ANOVA (b)

\begin{tabular}{|l|l|c|c|c|c|c|}
\hline Model & & Sum of Squares & Df & Mean Square & F & Sig. \\
\hline \multirow{4}{*}{1} & Regression & 37.959 & 1 & 37.959 & 114.026 & $.000(\mathrm{a})$ \\
\cline { 2 - 8 } & Residual & 33.623 & 101 & .333 & & \\
\cline { 2 - 8 } & Total & 71.582 & 102 & & & \\
\hline
\end{tabular}

Notes: ${ }^{a}$ Predictors: (Constant), EMPLOYEEBENEFITS. ${ }^{\mathrm{b}}$ Dependent Variable: JOBSATISFACTION (R square $=0.530)$. 
Fcal 114.026 at 0.0001 significance level.

Employee benefit significantly affects employee satisfaction in business.

Thus, the decision would be to reject the null hypothesis $\left(\mathrm{H}_{0}\right)$, and accept the alternative hypothesis $\left(\mathrm{H}_{1}\right)$.

Table 9. Coefficients (a)

\begin{tabular}{|l|l|c|c|c|c|c|}
\hline \multirow{2}{*}{ Model } & & \multicolumn{2}{|c|}{ Unstandardized Coefficients } & $\begin{array}{c}\text { Standardized } \\
\text { Coefficients }\end{array}$ & $\mathrm{T}$ & Sig. \\
\cline { 3 - 7 } & & $\mathrm{B}$ & Std. Error & Beta & $\mathrm{B}$ & Std. Error \\
\hline \multirow{2}{*}{1} & (Constant) & .910 & .268 & & 3.392 & .001 \\
\cline { 2 - 7 } & EMPLOYEEBENEFITS & .740 & .069 & .728 & 10.678 & .000 \\
\hline
\end{tabular}

Note: ${ }^{a}$ Dependent Variable: JOBSATISFACTION.

The model is shown mathematically as follows;

$Y=a+b x$

Where $y$ is increase in job satisfaction and $x$ is employee benefit,

$($ JOBSATISFACTION $)=0.910+0.740$ EMPLOYEEBENEFITS

This means that for every $100 \%$ change in employee satisfaction, employee benefit contributed $74 \%$. The result of findings of this research is applicable to the views and findings of Maloantoa, (2015); Ray \& Ray, (2011), Adeoye \& Field, (2014), Millan (2013), Noor (2013), Judge et al. (2010).

\section{Conclusion}

In this study, both statistical and theoretical findings indicated that reward system is a predictors of employee performance. However the findings revealed that reward systems are stronger and more significant predictor of employee performance. This research, therefore accepted that there is as positive relationship between reward systems and employees’ performance. Human resource managers should remain focused on managing the reward systems, increasing job satisfaction and increasing organizational commitment of the employees. The results of the study confirmed that employees benefit has a strong positive relationship with job satisfaction.

A key factor that could predict receiving bonus is job performance. This paper concluded that using bonuses and benefits increase productivity and organizational performance. The study has proved the effect of bonuses on employee motivation which indicated that the selection of more superior employees is enhanced if the contracts include a high cash bonus. Additionally, more frequently bonuses (quarterly) help to improve performance of the weak performers to achieve their annual sales quotas.

The study also concluded that bonuses and benefits could be used to manipulate employees and stimulate feelings of control and distrust. The conclusion generally is that advancing on reward processes usually impacts positively on the performance of the organizations. The conclusion of this study is valid in most sectors especially in the multinational food and manufacturing Industries.

\section{Recommendations}

Organizations need to have a reward system(s) as a standard. Not having a reward system in an organization will lead to resistance from the employees. Management, in studying how to address the performance of employees need to critically address the issue of reward systems as more than just the monthly compensation given to an employee. In building effective reward systems, management need to look at five key factors which are compensation, benefits, work life balance, development and career opportunities, performance and recognition.

Policies on wage administration, benefits, appraisal, promotion, qualification must be flexible, favorable and suitable and at such compliance becomes very easy. It has been discovered that some organizations fail to recognize employee effort and this can result in unhappy employees. Therefore it is important to evaluate the influence of reward system on employee's productivity in every organization for efficiency and performance.

The management and structuring of reward system should follow systematic and clearly laid out procedures which are tenable and feasible given. Incentive management and practices such as pay incentives and fringe 
benefits should be based on realistic and standard methods in accordance with industrial benchmarks, indices and procedures and should likewise conform to ethical valuations and practices.

\section{References}

1. Adeoye, A.O. and Z. Fields (2014). Compensation management and employee job satisfaction: A case of Nigeria. J. Soc. Sci., 41, 345-352.

2. Al-Hinai, Z.A. and A. Bajracharya (2014). A study on the factors affecting job satisfaction of academic staff in higher education institution. Proceedings of the 13th International Academic Conference, September 15-18, 2014, Antibes, France.

3. Artz, B. (2010). Fringe benefits and job satisfaction. Int. J. Manpower, 31, 626-644.

4. Asegid, A., T. Belachew and E. Yimam (2014). Factors influencing job satisfaction and anticipated turnover among nurses in Sidama zone public health facilities, South Ethiopia. Nursing Res. Pract.. 10.1155/2014/909768.

5. Aydogdu, S. and B. Asikgil (2011). An empirical study of the relationship among job satisfaction, organizational commitment and turnover intention. Int. Rev. Manage. Market., 1, 43-53.

6. Bagraim, J., T. Potgieter, C. Viedge and A. Werner (2007). Organisational Behaviuor. Van Schaik, Pretotria.

7. Bakan, I. and A.T. Buyukbese (2013). The relationship between employee's income level and employee job satisfaction: An empirical study. Int. J. Bus. Soc. Sci., 4, 18-25.

8. Bustamam, F.L., S.S. Teng and F.Z. Abdullah (2014). Reward management and job satisfaction among frontline employees in hotel industry in Malaysia. Proc. Social Behav. Sci., 144, 392-402.

9. Clark, A.E., N. Kristensen and N. Westergard-Nielsen (2009). Job satisfaction and co-worker wages: Status or signal? Econ. J., 119, 430-447.

10. Creswell, J.W. (2007). Educational Research: Planning, Conducting and Evaluating Quantitative and Qualitative Research. 3rd Edn., Prentice Hall, USA., ISBN-10: 0136135501, p. 670.

11. Daft, R. *2009). Organization Theory and Design. 10th Edn., Cengage Learning, USA., ISBN-13: 978-0324-59889-6, p. 649.

12. Ghafoor, M. (2014). Antecedents and consequences of job satisfaction: Evidence from Pakistani universities. Ph.D. Thesis, University of Dundee, Dundee.

13. Gordon, E.E. (2009). Winning the Global Talent Showdown. Berrett-Koehler Publishers, San Francisco.

14. Hussein, A.I. and A.R.D. Idris (2012). Structural equation models of management and decision-making styles with job satisfaction of academic staff in Malaysian Research University. Int. J. Educ. Manage., 26, 616-645.

15. Ibrahim, I.I. and A. Boerhaneoddin (2010). Is job satisfaction mediating the relationship between compensation structure and organisational commitment? A study in the Malaysian power utility. J. Global Bus. Econ., 1, 43-61.

16. Ismail, A. and M.R. Abd Razak (2016). A study on job satisfaction as a determinant of job motivation. Acta Universitatis Danabius, 12, 30-44.

17. Joshua, D. (2008). Internal factors influencing job satisfaction in a freight forwarding company. Master's Thesis, Durban University of Technology, Durban.

18. Judge, T.A., R.F. Piccolo, N.P. Podsakoff, J.C. Shaw and B.L. Rich (2010). The relationship between pay and job satisfaction: A meta-analysis of the literature. J. Vocational Behav., 77, 157-167.

19. Khan, M.S., I. Khan, G.M. Kundi, S. Khan, A. Nawaz, F. Khan and N.B. Yar (2014). The impact of job satisfaction and organizational commitment on the intention to leave among the academicians. Int. J. Acad. Res. Bus. Social Sci., 4, 114-131.

20. Kipkebut, D.J. (2010). Organisational commitment and job satisfaction in higher educational institutions: The Kenyan case. Ph.D. Thesis, Middlesex University, Middlesex.

21. Letele-Matabooe, M.J. (2012). An investigation into the factors influencing the levels of job satisfaction and organisational commitment of non-family employees working in family businesses. Master's Thesis, Nelson Mandela Metropolitan University, Port Elizabeth.

22. Machado-Taylor, M.D.L., V.M. Soares, J.B. Ferreira and O.M.R. Gouveia (2011). What factors of satisfaction and motivation are affecting the development of the academic career in Portuguese higher education institutions? Rev. Adm. Publica, 45, 33-44. 
23. Machado-Taylor, M.D.L., V.M. Soares, R. Brites, J.B. Ferreira, M. Farhangmehr, O.M.R. Gouveia and M. Peterson (2016). Academic job satisfaction and motivation: Findings from a nationwide study in Portuguese higher education. Stud. Higher Educ., 41, 541-559.

24. Mafini, C. and N. Dlodlo (2014). The relationship between extrinsic motivation, job satisfaction and life satisfaction amongst employees in a public organisation. S. Afr. J. Ind. Psychol., 40, 1-12.

25. Mangi, R.A., H.J. Soomro, I.A. Ghumro, A.R. Abidi and A.A. Jalbani (2011). A study of job satisfaction among non PHD faculty in universities. Aust. J. Bus. Manage. Res., 1, 83-90.

26. Mbundu, I.N. (2011). A critical evaluation of job satisfaction levels during the transitional period of a merger: The case of Walter Sisulu University. Master's Thesis, University of South Africa, Pretoria.

27. Millan, J.M., J. Hessels, R. Thurik and R. Aguado (2013). Determinants of job satisfaction: A European comparison of self-employed and paid employees. Small Bus. Econ., 40, 651-670.

28. Moloantoa, M.E. (2015). Factors affecting job satisfaction of academic employees: A case study of the National University of Lesotho. Master's Thesis, Durban University of Technology.

29. Mustapha, N. (2013). The influence of financial reward on job satisfaction among academic staffs at public universities in Kelantan, Malaysia. Int. J. Bus. Soc. Sci., 4, 244-248.

30. Noor, K.M. (2013). Job satisfaction of academics in Malaysian public higher education institutions. Masters Thesis, La Trobe University, Melbourne.

31. Ombima, H.P.A. (2014). Factors affecting employee job satisfaction in institutions of higher education in Kenya: A case study of United States International University (USIU). Ph.D. Thesis, United States International University-Africa.

32. Onukwube, H.N. (2012). Correlates of job satisfaction amongst quantity surveyors in consulting firms in Lagos, Nigeria. Aust. J. Construct. Econ. Build., 12, 43-54.

33. Ray, S. and I.A. Ray (2011). Human resource management practices and its effect on employee's job satisfaction: A study on selected small and medium sized iron and steel firms in India. Public Policy Admin. Res., 1, 22-31.

34. Rehman, M., A.K. Mahmood, R. Salleh and A. Amin (2013). Job satisfaction and knowledge sharing among computer and information science faculty members: A case of Malaysian universities. Res. J. Applied Sci. Eng. Technol., 7, 839-848.

35. Salisu, J.B., E. Chinyio and S. Suresh (2015). The impact of compensation on the job satisfaction of public sector construction workers of Jigawa state of Nigeria. Bus. Manage. Rev., 6, 282-296.

36. Sharp, T.P. (2008). Job satisfaction among psychiatric registered nurses in New England. J. Psychiatr. Mental Health Nurs., 15, 374-378.

37. Strydom, A. (2011). The job satisfaction of academic staff members on fixed-term employment contracts at South African higher education institutions. Ph.D. Thesis, University of Free State, Bloemfontein.

38. Swanepoel, B.J., B.J. Erasmus, H.W. Schenk and T. Tshilongamulenzhe (2014). South African Human Resource Management: Theory and Practice. 4th Edn., Juta, Cape Town.

39. Tella, A. C.O. Ayeni and S.O. Popoola (2007). Work motivation, job satisfaction and organisational commitment of library personnel in academic and research libraries in oyo state, Nigeria. Library Philosophy and Practice, Paper No. 118, April, 2007.

40. Terera, S.R. and H. Ngirande (2014). The impact of rewards on job satisfaction and employee retention. Mediterr. J. Soc. Sci., 5, 481-487.

41. Tettey, J.W. (2006). Staff Retention in African Universities: Elements of a Sustainable Strategy. The World Bank, Washington, DC.

42. Tezera, M. (2014). The relationship of reward management practices to employees' job satisfaction in Ethiopian insurance corporation. Master's Thesis, University of Addis Ababa.

43. Verret, L.B. (2012). Factors affecting university STEM faculty job satisfaction. Master's Thesis, Louisiana State University, USA. 